the decade ahead is not to ring with cries of "How do we keep up with China?". More, or better, public understanding of science is not a sufficient answer. It would be wrong to suppose that a science adviser, however able, would be able to solve these problems on his own; the post is, after all, an adviser's post, not one with ministerial power and responsibility. But May could help to change the way that ministers think.

There remains the business of talking and listening. Until the abrupt move of OST to the DTI, the British government had succeeded in stilling some of the most gruesome fears about the future of the British research enterprise by the willingness of OST's first minister, Mr William Waldegrave, and the head of OST, Professor William Stewart, to argue even unpopular cases in public. Openness, unsurprisingly, proved to be disarming. During the past two years, the result has been that the British research community has come to harbour a better appreciation of its own undisputed strengths. Why talking and listening should have this effect is not obvious, but is real enough; all policies are more persuasive when they are intelligible, which allows people to clear their minds for optimistic thoughts. If need be, May should take this task on his own shoulders, but science advisers everywhere should follow suit.

\section{Privatization in tears}

Newly private British water companies are in trouble with their first summer drought, and deserve to be.

AMONG the endless difficulties provoked by spinning off public monopolies into private ownership (see Nature 376, 451-452; 1995), one has just come to light: what happens if a private monopoly cannot fulfil its obligations to its customers? The place is Britain, "the cradle of privatization", whose rainfall is as heavy as any other country in Western Europe, the commodity is water and the hapless victims of a long-standing summer drought are the customers of the private companies (whose share prices are publicly quoted) which assumed responsibility for water supply just a few years ago. They have hardly been out of the newspaper headlines this year, first for rewarding their senior officials more handsomely than seems necessary, now for requiring that their customers cannot feed water to the grass and flowers that they grow because of a shortage of supply, made worse by the leakage of up to a third of what is available from the distribution system. If the water supply industry were still nationalized, complaints at the restrictions of the past few weeks would have been muted; government edict carries clout. Properly, private companies are less able to act in such a cavalier way. What are they, poor things, to do?

A few simple remedies from elsewhere in the world would not come amiss. Why not sell water by the cubic metre and stop offering an ad lib. supply in return for an annual fee, which is the British practice? Unaccountably, the water companies are busily resisting that thought, saying how much the installation of water meters would cost, per- haps $£ 4$ billion for the whole of Britain. But there is no way in which that reluctance can be sensible, either in economic or technical terms. Like all other commodity suppliers, the water companies suffer from peaks and troughs in the demand for their commodity, which means that their distribution networks must be more than minimally commodious. Their unique difficulty is that peak demand coincides with the times when the supply of surface water is at a minimum, which is why the companies imposing restrictions on water usage have been those whose supplies come from open reservoirs or rivers. There are probably as many people in Britain as there are elsewhere who would think twice about keeping a pet geranium alive if they had to pay pro rata for whatever it transpires each day.

That points to a wider issue. Water is not a scarce commodity in any temperate country, but the means for its collection, purification and distribution entail economic investment in reservoirs, pipelines and the like. At any particular time, the past volume of investment may be insufficient to allow the system to meet the present demand. (The water companies now say that they inherited many decades of inadequate investment, but why did they not arrange before they were privatized to borrow the money to make good the deficiencies?) But the needless or even feckless use of water, which may not matter when the supply is ample, is a waste of economic resources (and not of water) when demand and supply are out of balance. Economic signals that make that point, far from being anathema to the water industry, are essential for its well-being.

What can the poor companies do? One remedy is to invest more in the facilities of supply. That, too, will be expensive, of course, which is all the more reason for seeking to abate the horrors of peak demand by the use of water meters. (It is very curious that companies that have quickly learned to pay over-competitive salaries to their bosses should have been so slow to learn the rudiments of microeconomics.) But the equations could only come right in the long run. Indeed, the companies would find that they had a choice; either they could invest in facilities of their own, or they could buy pure water from elsewhere.

There are other ways of tackling the problem which have, by the technical standards of the water industry, futuristic components. In Britain, for example, why not ship water from one part of the country to another? This past summer, London has remained free of restrictions on the use of water because of the construction of a circular subterranean tunnel, at a depth of 300 metres, that serves both as a reservoir and a conduit for water. Why not extend that system a little further? Fears that the result would rob London of water would be legitimately offset by the knowledge that water from elsewhere would join the common pool. The water companies as they are would resist this notion also, saying that it would be uneconomic to invest such a large amount of money in guarding against a " 1 in 50 years" drought. Wise water companies would inform themselves on global warming at this stage. To urge them on, the British government should make the water companies pay compensation to the customers they are depriving of water . 